\title{
Pengembangan Bahan Ajar Berorientasi Literasi Kearifan Lokal di Madrasah Aliyah SwastaAl-Hikmah Soe Nusa Tenggara Timur
}

\author{
Syahrul $^{1}$, Arifin ${ }^{2}$, Amirulah Datuk ${ }^{3}$, Farid Fauzi Almu ${ }^{4}$, ST. Ramlah ${ }^{5}$ \\ Universitas Muhammadiyah Kupang ${ }^{1,2,3,4,5}$ \\ syahrulkadir7@gmail.com ${ }^{1}$, rifilatihan@yahoo.com², amirulahdatodawa@gmail.com², faridfauzi08@gmail.com ${ }^{4}$, \\ stramlah@gmail.com ${ }^{5}$
}

\begin{abstract}
The low quality of education in MAS Al-Hikmah Soe shows that teachers are still lacking in the ability to develop teaching materials due to lack of training. Therefore, this program aims to develop teaching materials based on the local wisdom of the Timorese. In this community service, using a dialogical method that is carried out with training directly to the teachers and students. The result is (1) the teacher's response in this activity has a strong effect on their ability to develop teaching materials based on local wisdom, because they did not realize and know that the values of local wisdom can be used as material to develop teaching materials, but after participating in training they realize that teaching material is not difficult, because there are many around us that can be used as teaching material. (2) The teacher's paradigm for smartphones has changed after attending this training, because they consider smartphones to be dangerous to students, but after attending this training they realize that smartphones are the future of human civilization that cannot be resisted, precisely the applications in them can be used as online learning media.
\end{abstract}

Keywords: Teaching Materials; Litercy, Local Wisdom

\begin{abstract}
Abstrak
Rendahnya mutu pendidikan di MAS Al-Hikmah Soe menunjukkan bahwa, guru-guru masih kurang dalam kemampuan mengembangkan bahan ajar akibat belum adanya pelatihan. Oleh karena itu, kegiatan ini bertujuan untuk mengembangkan bahan ajar berbasis kearifan lokal masyarakat Timor.Metode yang digunakan di dalam pengabdian masyarakat ini adalah metode dialogis yang dilakukan dengan kegiatan pelatihan secara langsung kepada para guru dan peserta didik. Hasil kegiatan menunjukkan bahwa (1) respon guru dalam kegiatan ini sengat berpengaruh terhadap kemampuan mereka dalam mengembangkan bahan ajar berbasis kearifan lokal, karena sebulumnya mereka tidak menyadari dan tidak tahu bahwa nilai-nilai kearifan lokal dapat dijadikan sebagai materi untuk mengembangkan bahan ajar, tetapi setelah mengikuti pelatihan mereka menyadari bahwa bahan ajar itu tidaklah sulit karena banyak disekeliling kita yang dapat dijadikan sebagai bahan ajar. (2) Paradigma guru terhadap smartphone mengalami perubahan setelah mengikuti pelatihan ini, karena mereka menganggap smartphone sengat berbahaya bagi peserta didik, tetapi setelah mengikuti pelatihan ini mereka meyadari bahwa smartphone adalah masadepan peradaban manusia yang tidak bisa dilawan, justru aplikasi di dalamnya dapat dimanfaatkan sebagai media pembelajaran online.
\end{abstract}

Kata Kunci: Bahan Ajar; Literasi; Kearifan Lokal 


\section{A. PENDAhuluan}

Mutu pendidikan di NTT (Nusa Tenggara Timur) selalu menempati posisi terbawah yaitu NTT hanya berada di posisi 24 dari terakhir setelah Provinsi Papua dan Papua Barat. Posisi ini dari tahun ke tahun tidak pernah mengalami perubahan (Salukh, 2018). Ini diperkuat dari beberapa observasi yang pernah dilakukan di Kabupaten TTS (Timor Tengah Selatan) tepatnya di MAS AlHikmah Soe menunjukkan bahwa lingkungan sokolah yang bahkan tidak memenuhi standar operasional pendidikan karena gedung sekolah yang hanya bersifat sementara. Terlebih lagi, fasilitas pendidikan seperti media dan perangkat pembelajaran yang tidak tersedia, dan tidak ada satu pun guru yang berstatus PNS yang ada hanya guru honorer. Keterbatasan fasilitas membatasi kemampuan guru untuk melakukan proses pembelajaran dan membatasi kemampuan peserta didik untuk menyerap pelajaran. Hal ini dikemukakan sendiri oleh beberapa guru di TTS bahwa rata-rata sekolah di NTT belum setara dengan sekolah-sekolah di daerah Jawa dan provinsi lainnya (Salukh, 2018).

Guru yang bergelar sarjana di NTT sebenarnya sudah banyak. Ini bisa dilihat dari beberapa perguruan tinggi yang memproduksi ribuan sarjana pendidikan setiap tahun. Namun, yang terjadi adalah angka pengangguran yang terus meningkat dan sekolah-sekolah di pedalaman yang sangat membutuhkan guru(Salukh, 2018). Ini sebagai bukti bahwa perguruan tinggi di NTT juga tidak sepenuhnya menghasilkan sarjana pendidikan yang memiliki konpetensi tinggi, sehingga persolan ini berdampak pada beberapa guru yang tidak kompeten dalam mendidik muridnya. Selain itu, terdapat beberapa hasil penelitian di sekolah-sekolah menunjukkan bahwa rata-rata murid SMA di NTT memiliki kemampuan bernalar yang rendah yang diakibatkan pola pengajaran yang salah dari guru-guru dan orangtua, akibatnya mutu pendidikan di NTT sangat rendah karena pengaruh psikologis dan sosiologis anak(Salukh, 2018).

Lebih jauh lagi, Pastor Mbula, ketua Majelis Nasional Pendidikan Katolik (MNPK), mengungkapkan bahwa rendahnya mutu pendidikan di NTT disebabkanoleh kualitas para guru, kepala sekolah dan buruknya perhatian pemerintah. Mereka masih kurang dalam hal leadership yang transformatif, serta kemampuan evaluasi dan monitoring yang baik(Djawa, 2017). Lebih lanjut, Djawa dan Mandela mengatakan bahwa rendahnya mutu pendidikan di NTT karena (1) kurangnya konsentrasi guru dan kepala sekolah terhadap pendidikan karena mereka lebih fokus mengurus proyek(Djawa, 2017), (2) kompetensi guru di NTT yang masih sangat rendah. (3) Semangat belajar anak-anak NTT yang masih sangat rendah. (4) Kurangnya fasilitas pendidikan di NTT, misalnya: kondisi ruang kelas yang tidak nyaman, keterbatasan kursi dan meja belajar, dan tidak ada media belajar sesuai tuntutan zaman (komputer, LCD)(Mandela, 2018).

Selain itu, nilai-nilai kearifan lokal masyarakat Timor sudah mulai dilupakan oleh guru-guru dan peserta didik. Merekalebih bangga terhadap budaya luar NTT. Padahal nilai-nilai kearifan lokal masyarakat Timor perlu dilestarikan, karenaitu adalah suatu ciri masyarakat NTT(Sandora et al., 2018). Permasalah yang dihadapi oleh guru di MAS Al-Hikmah Soe berdampak kepada peserta didik, tetapi kita juga tidak sepenuhnya menyalahkan guru karena masalah yang dihadapi oleh guru akibat dampak dari masalah lingkungan dan Pemerintah.

Di sisi lain, permasalahan yang dihadapi oleh guru adalah bahan ajar. Banyak guru yang mengeluhkan kurangnya bahan ajar akibat mereka sulit mendapatkan 
buku-buku yang dicetak di Jawa. Berdasarkan pada pesoalan ini, ternyata selama ini banyak guru yang menganggap bahwa bahan aja itu adalah hanya bersumber dari buku yang dicetak di Jawa dan dikirim ke NTT. Pada hal kalau kita membaca bebera buku teks yang digunakan sebagai bahan ajar di Mata Pelajaran Sosiologi atau IPS sumanya adalah berdasarkan pada pengalaman penulis di daerahnya masing-masing. Jadi sangat sulit jika guru yang ada di NTT harus memaksakan pembelajaran kearifan lokal orang Jawa pada anak-anak di NTT.

Berdasarkan hasil penelitian Laksana, kegagalan pendidikan di NTT akibat pembelajaran masih bersifat tradisional dan belum memanfaatkan teknologi informasi sebagai media pembelajaran, apalagi pada sekolah-sekolah yang berada di daerahpinggiran. Selain itu, peserta didik yang bersekolah rata-rata berasaldari keluarga menengah ke bawah, sehingga guru hanya memanfaatkan buku-buku sederhana sebagaimedia pembelajaran (Laksana et al., 2018). Lebih jauh lagi, banyak guru yang hanya menggunakan bahan ajar seperti buku teksdan LKS yang disediakan oleh pemerintah yang mungkin tidak sesuai dengan nilai-nilai kearifan lokal masyarakat NTT(Laksana et al., 2018).

Untuk mengatasi persoalan di atas, guru harus mampumengolah serta menelaah kearifan lokal yang ada pada masyarakat Timoragar dapat diserap lebih cepat oleh peserta didik di dalam pembelajaran(Asna and Purwaningsih, 2019).Oleh karena itu, guru dan peserta didik perlu mengikuti pelatihan literasi kearifan lokal, literasi media pembelajaran online, dan penyusunanbahan ajar berbasis kearifan lokal (Oktaviani et al., 2017). Sehingga kegiatan pengabdian ini penting dilakukan karena sangat membantu guru-guru dan peserta didik dalam pembelajaran.

\section{B. PELAKSANAAN DAN METODE}

Kegiatan pengabdian ini diselenggaran oleh Fakutas Keguruan dan Ilmu Pendidikan (FKIP), Universitas Muhammadiyah Kupang (UMK) pada tanggal 16 April 2019 sebagai salah satu kegiatan rutin yang dilaksanakan setiap semester. Di dalam pengabdian ini, dibagi atas beberapa tim salah satunya adalah tim Prodi Pendidikan Sosiologi. Pengabdian ini berlokasi di MAS Al-Hikmah Soe, Kabupaten Timor Tengah Selatan (TTS), NTT. Pengabdian ini difokuskan pada guruguru yang terdiri dari 9 orang dan peserta didik 57 orang.

Pertama, Persiapan: Sebelum melakukan pelatihan, 30 hari sebelumnya dilakukan observasi di Kabupaten TTS oleh beberapa orang perwakilan masing-masing Tim Prodi. Berdasarkan hasil analisis data observasi, maka Tim Prodi Pendidikan Sosiologi relevan dengan tema kegiatan di MAS Al-Hikmah Soe. Persiapan selanjutnya adalah para tim melakukan perjalan ke Kabupaten TTS. Setelah tiba di sekolah, tim melakukan pembagian materi yaitu 2 orang memberikan pelatihan pengembangan bahan ajar berbasis kearifan lokal dan media pembelajaran online kepada guru-guru dan 2 orang memberikan pelatihan literasi kearifan lokal kepada peserta didik.

Kedua,

Pelaksanaan

Pelatihan:Pelatihan dilakukan dengan dua ruang kelas, yaitu ruangan untuk pelatihan guru-guru dan peserta didik. Di dalam pelatihan ini, masing-masing kelas menggunakan infocus juga disertai dengan papan tulis dan alat peraga lainnya. Pelatihan tiap-tiap kelas dibagi ke dalam dua sesi: (1) Kelas guru, sesi pertama membahas tentang "Pengembangan Bahan Ajar Berbasis Kearifan Lokal", dan sesi kedua membahas tentang "Pengembangan Media Pembelajaran Online", sedangakan (2) Kelas peserta didik, sesi pertama membahas 
tentang "Literasi Kearifan Lokal", dan sesi kedua membahas "Literasi Media Online".

Ketiga, Evaluasi: Evaluasi dilakukan dengan dialog dan tanya jawab dengan peserta didik setelahkegiatan dilakukan. Yaitu dilihat dari kemampuan dan kualitas setiap pertanyaan dan jawan peserta didik yang diberikan oleh pemateri. Secaraumum, peserta didik antusias mengikuti pelatihan apalagi banyak peserta didik yang baru menyadari pentingnya kearifan lokal untuk selalu di lestarikan.Selain itu, evaluasi tatap muka juga dilakukan denganguru-guru serta memberikan angketa yang berisi pertanyaan-pertanyaan yang relevan dengan tema. Data yang diperoleh melalui angket dianalisi, dilakukan refleksi dan dievaluasi.

\section{C.HASIL DAN PEMBAHASAN}

Secara umum pengembangan bahan ajar yang telah dilakukan di MAS Al-Hikmah Soe tersusun dari dua bagian utama, yaitu: (1) Pengembangan pemetaan indikator pembelajaran adalah menampilkan peta indikator untuk materi kearifan lokal yangmenjadi fokus dalam pembelajaran yang bertujuan untuk meghubungkan danmempermudah alur pikir guru dalam menyajikan dan mengelola pembelajaran, sehingga peserta didik dapat mengikuti peta tersebut dengan terintegrasi berdasarkan nilainilai budaya dan kearifan lokal masyarakat Timor. (2) Pengembangan informasi atau penambahan informasi adalah pemberian informasi untuk menambahpengetahuan peserta didik tentang potensi daerah NTT khususnya kabupaten TTS, misalnya nilainilai budaya dan kearifan lokal masyarakat Timor. Hal ini penting dikembangakn oleh guru untuk meningkatkan rasa ingin tahu peserta didik mengenai kearifan lokal masyarakat Timor (Laksana et al., 2018). Selain itu, kegiatan ini dilakukan tiga pengembangan secara khusus, yaitu pengembangan bahan ajar berbasis kearifan lokal yang difokuskan pada guru-guru, literasi kearifan lokal pada peserta didik, dan literasi media pembelajaran online pada guru dan peserta didik.

\section{Pengembangan Bahan Ajar Berbasis Kearifan Lokal}

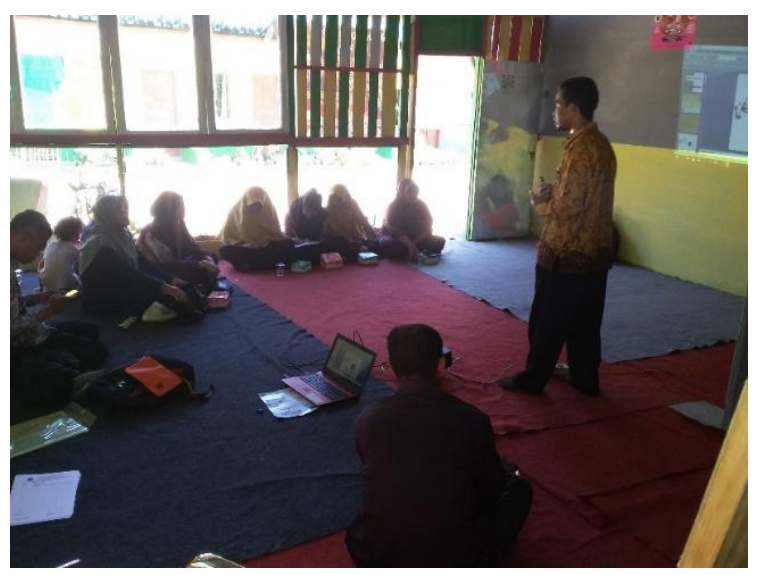

Gambar 1.Pelatihan Pengembangan Bahan Ajar kepada Guru MAS Al-Hikmah Soe

Pengembangan bahan ajar berbasis kearifan lokal di MAS Al-Hikmah Soe dilakukan melalui beberapa tahapan. Pertama, analisis kebutuhan bahan ajar berbasis kearifan lokal. Tahapan ini memetakan beragam kebutuhan seperti nilainilai kerifan lokal masyarakat Timor yang diperlukan oleh guru dalam proses pembelajaran, mulai dari karakteristik masyarakat Timor, tradisi dan sistem kepercayaan masyarakat Timor, struktur sosial masyarakat Timor,adat istiadat masyarakat Timor, upacara adat masyarakat Timor dan tradisi kebudayaan lainnya yang dianggap berhubungan dengan materi ajar yang mendukung proses pembelajaran. Oleh karena itu, dalam mengintegrasikan nilainilai kearfian lokal tersebut maka dilakukan program literasi kearifan lokal kepada para guru agar memiliki kesiapan dalam mengembangkannya menjadi sebuah bahan ajar. Di dalam kegiatan ini, pemetaan kebutuhan bahan ajar menjadi salah satu tahap yang sangat penting dilakukan untuk 
memberikan hasil yang optimal dalam pengembangan bahan ajar berbasis kearifan lokal yang dilakukan oleh guru di MAS AlHikmah Soe. Selain itu, analisis kebutuhan juga memetakan materi-materi kearifan lokal yang tidakmudah dipahami oleh guru demi mengoptimalkan danmempermudah pemahamanguru terhadap bahan ajar berbasis kearifan lokal yang akan diajarkan.

Kedua, penyusunan bahan ajar berbasis kearifan lokal. Tahap ini dilakukan pembuatan bahan ajar dari nilai-nilai kearifan lokal masyarakat Timor yang nantinya akan digunakan dan menjadibahan awal untuk diolah menjadi media pembelajaran. Nilainilai kearifan lokal yang telah dikembangkan menjadi bahan ajar menuntut pemahan para guru dalam menyesuaikan dengan pengembanganbahan ajar. Materi ajar yang disampaikan tidakakan sama dengan materi yang ada di dalam buku teks,karena materi kearifan lokal masyarakat Timor hanya dipahami oleh orang-orang Timor itu sendiri, sehingga guru perlu menjadikan buku-buku teks sebagai referensi, tetapi materi yang diajarkan oleh guru tidak harus memuat semua yang ada di dalam buku tekskarena akan menyulitkan dalam pembelajaran jikan memuat materi terlalu banyak. Materiyang dikembangkan hanya materi yangmendorong peserta didik menemukan konsepkearifan lokal masyarakat Timor disertai dengan contoh-contoh realitas kearifal lokal masyarakat Timor, karenadekat dengan kehidupan peserta didik demi kedalaman danpemahaman materi.

Ketiga, workshop dan simulasi pengembangan bahan ajar berbasis kearifan lokal.Kegiatan inimelibatkan guru untuk mengembangkan bahanajar dengan budaya lokal masyarakat Timor. Pelatihan terhadap guru sebagai cara untuk melakukanakselerasi terhadap keterampilan dalam mengembangkan dan melakukan inovasiterhadap bahan ajar agar relevan dengan nilai-nilai kearifan lokal
(Hendrastomo and Januarti, 2018). Bahan ajar yangdikembangkan secara langsung oleh guru akanmemiliki kelebihan, karena materi ajar akandisesuaikan dengan kearifan lokal masyarakat.Dalam kegiatan ini, melibatkan semua guru di MAS Al-Hikmah Soe untuk melakukan simulasi pengembangan bahan ajar, danjuga dilakukan diskusi dengan semua guruyang tergabung dalam MGMP guru IPS dan sosiologi di TTS. Diskusi ini dilakukan sebagai saranapengungkapan ide seperti para guru memberikan ide dansarana serta melakukan eksplorasiterhadap bahan ajar yang berbasis kearifan lokal, sehingga bahan ajar yangdikembangkan bisa di terapkan di semua sekolahdi Kabupaten TTS.

Keempat, evaluasi bahanajar berbasis kearifan lokal yang telah dirancang oleh para guru. Tahap ini memberikan masukan kepada para guru terkaitdengan bahan ajar yang telah mereka buat, mulaidari sistematika hingga bayangan ketika akandigunakan, kesesuaian dengan karakteristikpeserta didik, hingga kemudahan dalam halaksesibilitas antar halaman (Hendrastomo and Januarti, 2018). Pengembangan bahan ajar berbasis kearifan lokal ini membutuhkan pemahaman penuh tentang budaya dan kearifan lokal masyarakat Timor. Oleh karena itu, dalam kegiatan ini dilakukan evaluasi bahan ajar yang telah dibuat oleh guru untuk mencari kelayakan sebagai materi ajar. Di dalam evaluasi ini, guru-guru meberikan sinyal positif terhadap kelayakan bahan ajar dan pemahaman terhadap budaya dan kearifan lokal masyarakat Timor.Sehingga dapat disimpulkan bahwa guru di MAS AlHikmah Soe sudah layak dan bisa menerapakan bahan ajar berbasis kearifan lokal yang mereka kembangkan secara mandiri. 


\section{Literasi Kearifan Lokal pada Peserta Didik}

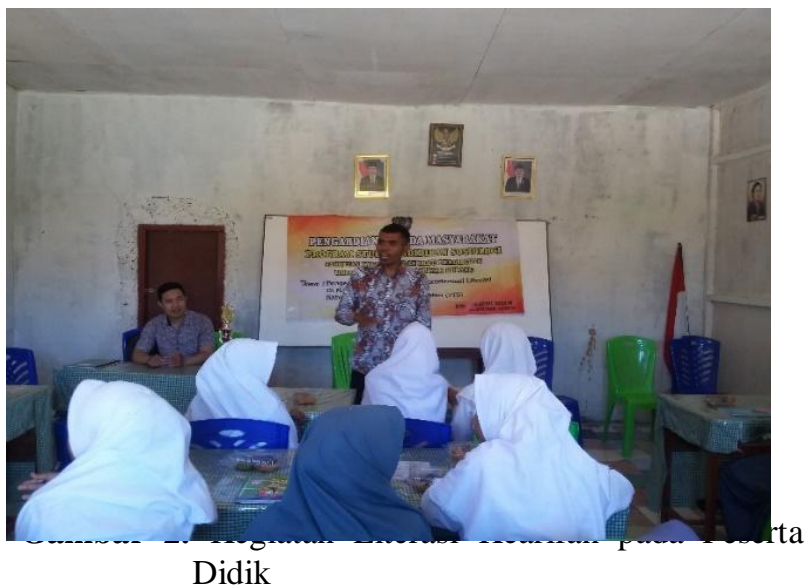

Menumbuhkan budaya literasi kearifan lokal masyarakat Timor dilakukan secara langsung berhadapan dengan peserta didik. Ini dilakukan demi memudahkan peserta didik dalam menerima materi berbasis kearifan lokal yang akan diajarkan oleh guru. Dalam pengantar literasi kearifan lokal ini, pemateri memanfaatkan bahan yang tersedia di ruangkelas, misalnya tulisan, gambar, atau poster yang ada hibungannya denga kebudayaan masyarakat Timor, salah satunya adalah menghiasi ruang kelas dengan Batik khas Timor. Dinding dapat ditempeli beberapa jenis gambar atau poster yang telah dibuat oleh peserta didik dengan memberikan atau menuliskan makna kebudayaan atau filosofis pada masing-masing gambar batik tersebut.Penjelasan ini memberikan pemahan pada peserta didik bahwa yang bersifa ilmu tidak hanya materi-materi yang berasal dari buku, tetapi nilai-nilai budaya dan kearifan lokal masyarakat Timor dan lagu-lagu daerah mereka adalah sebuh sumber ilmu yang kaya dan bermanfaat bagi mereka.

Pada umumnya, peserta didik di MAS Al-Hikmah Soe sudah sangat paham dengan budaya lokal masyarakat Timor, karena tradisi kebudayaan ini masih dijaga oleh masyarakat setempat, bahkan dalam berbagai acara sering dipertunjukkan. Peserta didik di sekolah ini terdiri dari penduduk asli dan pendatang dari pula Jawa dan Sulawesi serta pulau lainnya. Meskipun sebagian besar anak-anak ini bukan penduduk asli, tetapi mereka sangat memahami budaya dan kearifan lokal masyarakat Timor, karena sejak kecil masyarakt setempat sudah memperkenalkan kepada orang-orang pendatang. Namun dalam kegiatan ini, tetap difokuskan pada penumbuhan literasi kearifan lokal agar peserta didik tidak hanya menilai budaya tersebut sebagai tradisi, tetapi dapat menjadi ilmu pengetahuan bagi mereka.

Guru menyusun bahan ajar ini agar peserta didik mendapat gambaran yang jelas dan rinci dalammenerima pelajaran berbasis kearifan lokal masyarakat Timor. Bahan ajar yang dikembangkan oleh guru adalah sebagai berikut: (1) Pemetaan indikator pembelajaran, yaitu guru menampilkan peta bahan ajar kearifan lokal agar dapat meghubungkan danmempermudah alur pikir peserta didik dalam menerima materi, dan peserta didik juga dapat mengikuti peta tersebut dengan terintegrasi berdasarkan kearifan lokal masyarakat Timor (Laksana et al., 2018). (2) Mengembangkan pengalaman belajar peserta didik melalui kegiata "ayo berkarya", misalnya guru melati pesert didik dalam mengintegrasikan nilai-nilai budaya dan kearifan lokal masyarakat Timor seperti cara membuat Batik Timor, menginterpretasi kearifan lokal masyarakat Timor menjadi sebuh makna filosofis atau bahkan menjadi teori-teori sosial, dan berbagai kreativitas lainnya; (3) Melakukan diskusi dengan mengembangkan bahan ajar dari materi keraifan lokal masyarakat Timor, misalnya diskusi tentang pluralitas agama, bahasa dan tradisi lainnya. Kegiatan diskusi ini dapat menumbuhkan literasi peserta didik pada keterampilan berbahasa, toleransi, dialogisdan kemampuan berpikir sistematis (Laksana et al., 2018).

\section{Literasi Media Pembelajaran Online pada Guru dan Peserta Didik}


Beberapa guru di MAS Al-Hikmah Soe telahmemanfaatkan akses internet untuk menunjangproses pembelajaran. Dibalik ketidakmemadaian fasilitas dan gedung di sekolah tersebut, para guru masih semangat dalam memanfaatkan media online sebagai bahan ajar, karena beberapa gurumenyadari bahwa media online sangat mendukung proses pembelajaran. Namun saat ini, mereka masih terkendala dalam penggunakan media online tersebut. Oleh karena itu, kegiatan lietrasi ini dilakukan untuk mengembangkan pemahan guru MAS Al-Hikmah Soe terhadap media online yang dapat digunakan sebagai bahan ajar. Pengembangan bahan ajar inimemanfaatkan kemajuan teknologi untukmemaparkan materi ajar berbasis kearifan lokal. Adabanyak aplikasi yang dapat dimanfaatkan oleh guru untuk mengembangkan bahan ajar(Sitompul et al., 2019), mulai daripenggunaan media pembelajaran seperti penggunaan powerpoint, penggunaan website/internet hingga video dariyoutube maupun video blog (vlog), dan smartphone (Hendrastomo and Januarti, 2018)(Syahrul, 2019).

\section{Di MAS Al-Hikmah Soe,} pengembangan bahan ajar yang memanfaatkan teknologiinformasi belum dilakukan sama sekali, bahkan peserta didik dilarang membawa smartphone ke sekolah. Sedang beberapa sekolah-sekolah unggulan di pulau Jawa dan Sulawesi justrus peserta didik dianjurkan untuk membawa smartphone ke sekolah karena dapat dijadikan sebagai media pembelajaran online. Oleh karena itu, di dalam pelatihan ini diberikan sebuah pemahaman kepada para guru agar situasi ini perludisikapi sebagai peluang untukmemanfaatkan perangkat elektronik yangdimiliki peserta didik sebagai media pembelajaran online. Misalnya, melalui smartphonepeserta didik bisa melakukan beragamkegiatan untuk mencari materipelajaran, bersosialisasi denganmedia sosial, berkomunikasi hingga bermaingames. Berbagai aplikasi tersebut apabila tidakdikelolah dengan baik oleh peserta didik maka akan lebih banyakdigunakan untuk hal-hal yang kurang produktif, tetapi apabila guru dapat bekerjasama dengan peserta didik dalam memafaatkan aplikasi smartphone menjadi sebuah media pembelajaran online maka akan memberi manfaat yang positif (Hendrastomo and Januarti, 2018)(Wijayanti and Ayuningtyas, 2019).

Menyikapi persoalan di atas maka literasi media pembeljaran online penting untuk para guru di MAS Al-Hikmah Soe, karena kebayakan guru-guru tersebut memiliki smartphone tetapi mereka tidak tahu cara penggunaannya sebagai media pembelajaran online. Sehingga mereka cenderung menganggap smartphone sebagai perangkat elektronik yang berbahaya bagi peserta didik. Di sisi lain, aplikasi media pembelajaran online saat ini sangat mudah didapat dan telah dijadikan sebagai media pembelajaran online di beberapa sekolah unggulan. Pada umumnya,aplikasi ini dapat dengan mudah dan gratisdiunduh melalui playstore (android) dan applestore (ios). Lebih jauh lagi, smartphonebisa dipergunakan untuk berselancar di dunia maya melalui website yang mampumenghubungkan keingintahuan seseorangdengan pengetahuan yang ada (Hendrastomo and Januarti, 2018).

Saat ini hampir semua guru di MAS Al-Hikmah Soe memiliki smartphone, hanya saja smartphone yangdipakai masih lebih banyak digunakan untuksarana sosial media, bermain games, nonton youtube dansearching(Hendrastomo and Januarti, 2018). Di sisi lain, kondisi MAS Al-Hikmah Soe cukup memprihatinkan, karena beragam timpang antara sekolah favorit dengan sekolah miskinyang ada di NTT. Sarana danprasarana di MAS Al-Hikmah Soe kurang mendukung untukdilaksanakannya 
pembelajaran denganmenggunakan teknologi informasi. Aksesinternet tidak tersedia di sekolah ini,apa lagi harus berlangganan wifi, kebanyakan guru dan peserta didik hanya berlangganan paket datauntuk bisa mengakses internet. Kemiskinan yang kemudian membuat sekolah ini sulit memberikan kemudahanbagi guru dan peserta didik untukmengembangkan pembelajaran denganmenggunakan peralatan teknologi informasi (Syahrul and Wardana, 2018). Oleh karena itu, salah satu cara hanya dengan menggunakan smartphone.

\section{PENUTUP}

\section{Simpulan}

\begin{tabular}{ccc}
\multicolumn{2}{c}{ Pengabdian masyarakat yang } \\
dilakukan di MAS Al-Hikmah Soe
\end{tabular} menunjukkan beberapa hal utama dalam kegiatan ini, yaitu (1) respon guru dalam kegiatan ini sengat berpengaruh terhadap ketertarikan mereka dalam mengembangkan bahan ajar. Ini dapat dilihat dari hasi evaluasi kegiatan yang menunjukkan bahwa guru-guru selama ini tidak menyadari bahwa nilai-nilai kearifan lokal itu penting untuk diintegrasikan menjadi materi ajar, tetapi setelah mengikuti pelatihan ini mereka tidak lagi kesulitan untuk mencari bahan ajar. (2) Paradigma guru terhadap smartphone mengalami perubahan setelah mengikuti pelatihan ini. Sebelumnya mereka menganggap smartphone sengat berbahaya pada peserta didik karena mengandung konten-konten yang negatif, tetapi setelah mengikuti pelatihan ini mereka meyadari bahwa smartphone adalah masadepan media pembelajaran.

\section{Saran}

Dalam pengabdian ini, kami menyadari masihbanyak program kegiatan yang tidak dapat kami laksanakan sekaligus. Oleh karena itu, kami menyarankan agar kegiatan pengabdian masyarakat selanjutnya dapat mempersiapakan waktu sekitar satu bulan dan menambah biaya kegiatan.

\section{Ucapan Terima Kasih}

Kami sampaikan banyak terima kasih kepada Dekan FKIP UMK yang telah membantu dan mendanai pengabdian masyarakat ini. Kami juga mengucapkan banyak terima kasih kepada MAS AlHikmah Soe NTT yang telah menyediakan tempat dan bersedia bekerjasama.

\section{E. DAFTAR PUSTAKA}

Asna, K., Purwaningsih, S.M., 2019. Pemanfaatan Bahan Ajar Sejarah dengan Pendekatan Ilmu-Ilmu Sosial untuk Meningkatkan Hasil Belajar Siswa Kelas XII IPS 1 SMA Negeri 1 Trenggalek. Avatara 7.

Djawa, P., 2017. Rendahnya Kualitas Pendidikan di NTT. Apa Sebab? \& Salah Siapa? Peter Djawa Website. URL

https://peterdjawa.wordpress.com/20 17/12/07/kualitas-pendidikan-nttrendah-apa-penyebabnya/

Hendrastomo, G., Januarti, N.E., 2018. Metode Pengembangan Bahan Ajar Berbasis Teknologi Informasi Bagi Guru Sosiologi Kabupaten Purworejo (Aplikasi Game Html 5 Dengan Construct 2). Habitus: Jurnal Pendidikan, Sosiologi, dan Antropologi 2, 92-104.

Laksana, D.N.L., Kurniawan, P.A.W., Niftalia, I., 2018. Pengembangan Bahan Ajar Tematik SD Kelas IV Berbasis Kearifan Lokal Masyarakat Ngada. Jurnal Ilmiah Pendidikan Citra Bakti 3, 1-10.

Mandela, H., 2018. Mencermati Fenomena Mutu Pendidikan di NTT - Suara Flores. Suara Plores. URL http://www.suaraflores.net/mencerm 
ati-fenomena-mutu-pendidikan-di-ntt/.

Oktaviani, I., Zaliana, E., Ratnasari, Y., 2017. Menggagas Kajian Kearifan Budaya Lokal di Sekolah Dasar Melalui Gerakan Literasi Sekolah, in: Aktuali Kurikulum 2013 Di Sekolah Dasar Melalui Gerakan Literasi Sekolah Untuk Menyiapkan Generasi Unggul Dan Berbudi Pekerti. Presented at the Seminar Nasional, PGSD Universitas Muria Kudus, Kudus.

Salukh, N.A., 2018. Mencari Jalan Keluar Masalah Pendidikan di NTT [WWW Document]. Mencari Jalan Keluar Masalah Pendidikan di NTT. URL https://www.kompasiana.com/neno106 9/5b0c2b0b5e137339a12cad93/masala h-pendidikan-di-nt

Sandora, C.D., Yolida, B., Marpaung, R.R.T., 2018. Efektivitas Bahan Ajar Berbasis Kearifan Lokal Di SDN 1 Kuripan. Jurnal Bioterdidik: Wahana Ekspresi Ilmiah 6.

Sitompul, N.C., Rufi'i, Leksono, I.P., Rejeki, H.W., $2019 . \quad$ Meningkatkan Kompetensi Pendidik di Era Pembelajaran Abad 21 dengan Menjadi Guru Blogger. JPM (Jurnal Pemberdayaan Masyarakat) 4, 330338.

Syahrul, 2019. Pendidikan Alternatif untuk Komunitas Tertindas. CV. Sarnu Untung, Yogyakarta.

Syahrul, S., Wardana, A., 2018. Analisis kebijakan pendidikan untuk anak jalanan di Kota Yogyakarta. hsjpi 4, 117.
Wijayanti, E.P., Ayuningtyas, F., 2019. Peningkatan Budaya Literasi Anak di Taman Kanak-Kanak Nurul Fikri Bekasi Utara. JPM (Jurnal Pemberdayaan Masyarakat) 4, 291299. 